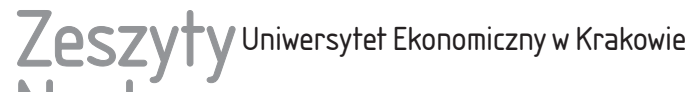 Naukowe
}

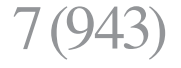

ISSN 1898-6447

Zesz. Nauk. UEK, 2015; 7 (943): 95-109 DOI: 10.15678/ZNUEK.2015.0943.0706

Katarzyna Frodyma

Katedra Statystyki

Uniwersytet Ekonomiczny w Krakowie

\section{Wpływ wykorzystywanych źródeł energii na stan środowiska naturalnego w Polsce ${ }^{*}$}

\section{Streszczenie}

Wykorzystanie różnych źródeł energii stanowi coraz poważniejsze wyzwanie dla krajów, dla których zrównoważony rozwój oznacza także lepsze wykorzystanie surowców energetycznych oraz poprawę stanu środowiska. Produkcja energii i jej wykorzystywanie wpływa na podniesienie poziomu naszego życia, ale jednocześnie powoduje degradację i niszczenie środowiska naturalnego. Głównym celem badań jest ocena wpływu wykorzystywanych źródeł energii na stan środowiska naturalnego w Polsce. Omówione zostały zmiany w strukturze pozyskania energii ze źródeł tradycyjnych i odnawialnych w poszczególnych województwach w Polsce. Przeprowadzono analizę stanu środowiska naturalnego ze szczególnym uwzględnieniem zanieczyszczenia powietrza i wody. Podjęto próbę oceny, czy zwiększające się wykorzystanie odnawialnych źródeł energii ma pozytywny wpływ na zmniejszenie degradacji środowiska naturalnego.

Słowa kluczowe: energia ze źródeł odnawialnych, zanieczyszczenie powietrza i wody, liniowe uporządkowanie, grupowanie.

* Artykuł powstał w ramach realizacji tematu badawczego finansowanego ze środków przyznanych Wydziałowi Zarządzania Uniwersytetu Ekonomicznego w Krakowie, w ramach dotacji na utrzymanie potencjału badawczego. 


\section{Wprowadzenie}

Jednym z priorytetów Unii Europejskiej jest zwiększenie udziału energii ze źródeł odnawialnych w bilansie pierwotnych nośników energii dla Unii jako całości. W 2009 r. przyjęto pakiet znany jako cel 20-20-20 (Dyrektywa 2009/28/ WE z dnia 23 kwietnia 2009 r.). Ten pakiet klimatyczno-energetyczny obejmuje cele na 2020 r. w zakresie zarówno zużycia energii (zmniejszenie o 20\% zużycia energii pierwotnej w porównaniu z przewidywanymi poziomami, zmniejszenie to ma zostać osiągnięte poprzez poprawę efektywności energetycznej), jak i wytycznych dotyczących energii ze źródeł odnawialnych (co najmniej 20\% końcowego zużycia energii brutto w UE ma pochodzić z odnawialnych źródeł energii oraz co najmniej $10 \%$ końcowego zużycia energii transportowych pochodzić ma z odnawialnych źródeł energii), ponadto dyrektywa ta odnosi się do zagadnień zanieczyszczenia powietrza (redukcja emisji gazów cieplarnianych w UE o co najmniej 20\% poniżej poziomu z $1990 \mathrm{r}$.).

Tak duży nacisk na wykorzystanie odnawialnych źródeł energii wynika po pierwsze z faktu, że tradycyjne (kopalniane) źródła energii mogą się wyczerpać, szczególnie biorąc pod uwagę zwiększające się światowe zapotrzebowanie na energię elektryczną, po drugie, w ogólnym przekonaniu wykorzystywanie odnawialnych źródeł energii w mniejszym stopniu powoduje zanieczyszczenie środowiska. Głównym celem badań jest ocena wpływu wykorzystywanych źródeł energii na stan środowiska naturalnego w Polsce. W artykule omówiono zmiany w strukturze pozyskania energii ze źródeł tradycyjnych i odnawialnych w poszczególnych województwach w Polsce. Dokonano także analizy stanu środowiska naturalnego ze szczególnym uwzględnieniem zanieczyszczenia powietrza i wody, a także podjęto próbę oceny, czy zwiększające się wykorzystanie odnawialnych źródeł energii ma pozytywny wpływ na zmniejszenie degradacji środowiska naturalnego w zakresie zanieczyszczenia powietrza i wody. Hipoteza badawcza brzmi, że wzrost wykorzystania odnawialnych źródeł energii wpływa na mniejsze zanieczyszczenie środowiska naturalnego.

\section{Produkcja energii elektrycznej w Polsce}

Najwięcej energii elektrycznej w przeliczeniu na 100 tys. mieszkańców produkuje się (www.stat.gov.pl, dostęp: 20.09.2014 r.) w województwie łódzkim, a najmniej w województwie warmińsko-mazurskim (por. rys. 1). Jeśli zaś chodzi o energię elektryczną z odnawialnych źródeł energii, to największa produkcja jest w województwie zachodniopomorskim, a najmniejsza w lubelskim. Najwyższym odsetkiem energii elektrycznej ze źródeł odnawialnych w produkcji energii elek- 


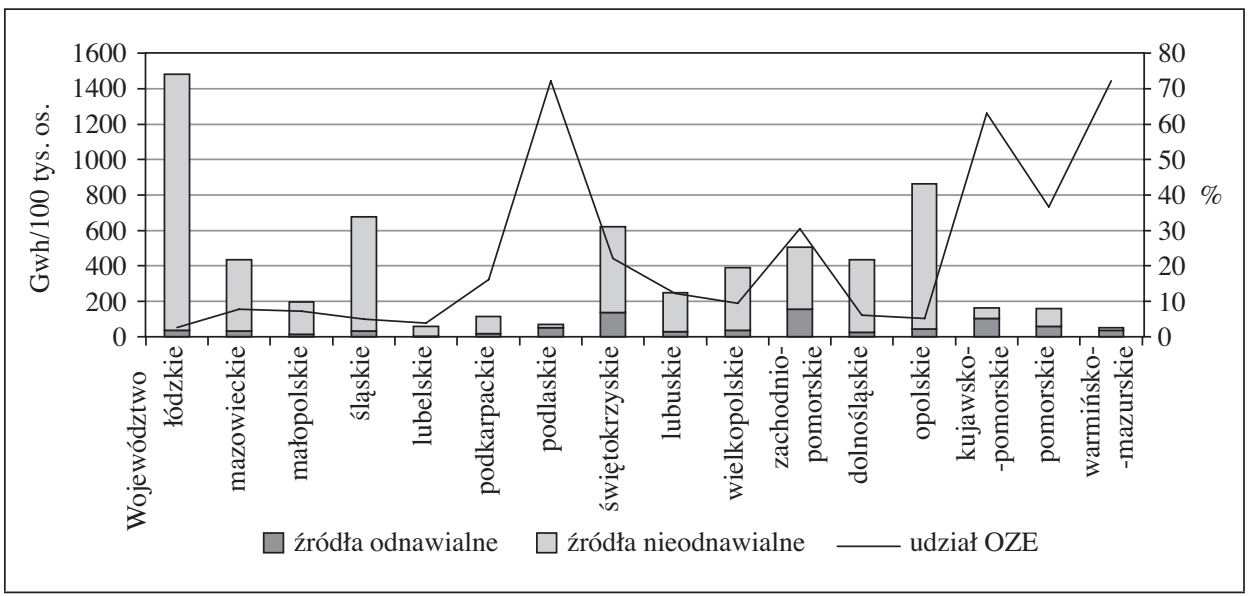

Rys. 1. Produkcja energii elektrycznej w GWh w przeliczeniu na 100 tys. mieszkańców w Polsce w 2013 r. według źródeł

Źródło: opracowanie własne.

Tabela 1. Zmiany wielkości produkcji w Polsce w 2013 r. w stosunku do 2005 r. (w \%)

\begin{tabular}{|l|c|c|c|}
\hline Województwo & $\begin{array}{c}\text { Zmiana wielkości } \\
\text { produkcji energii } \\
\text { elektrycznej }\end{array}$ & $\begin{array}{c}\text { Zmiana wielkości } \\
\text { produkcji energii } \\
\text { elektrycznej ze źródeł } \\
\text { odnawialnych }\end{array}$ & $\begin{array}{c}\text { Zmiana wielkości } \\
\text { produkcji energii } \\
\text { elektrycznej ze źródeł } \\
\text { nieodnawialnych }\end{array}$ \\
\hline Łódzkie & 21 & 1585 & 18 \\
\hline Mazowieckie & 7 & 860 & -1 \\
\hline Małopolskie & -28 & -3 & -29 \\
\hline Śląskie & 0 & 1450 & -5 \\
\hline Lubelskie & -45 & 430 & -47 \\
\hline Podkarpackie & -8 & 126 & -17 \\
\hline Podlaskie & 31 & 7157 & -63 \\
\hline Świętokrzyskie & 57 & 441 & 30 \\
\hline Lubuskie & 15 & 103 & -11 \\
\hline Wielkopolskie & -2 & 1278 & 15 \\
\hline Zachodniopomorskie & 56 & 756 & -24 \\
\hline Dolnośląskie & -20 & 266 & -7 \\
\hline Opolskie & -4 & 226 & -31 \\
\hline Kujawsko-pomorskie & 13 & 77 & -27 \\
\hline Pomorskie & 3 & 253 & -15 \\
\hline Warmińsko-mazurskie & 155 & 999 & \\
\hline Znóle & & & 8 \\
\hline
\end{tabular}

Źródło: opracowanie własne. 
trycznej ogółem charakteryzuje się województwo podlaskie (72,3\%), warmińsko-mazurskie $(72,3 \%)$ i kujawsko-pomorskie $(63,1 \%)$, a najmniejszym łódzkie (tylko $2,6 \%)$.

Zmiany wielkości produkcji w poszczególnych województwach prezentuje tabela 1. W sześciu województwach w 2013 r. nastąpił spadek produkcji energii elektrycznej w stosunku do 2005 r. Największy wzrost nastąpił w województwie warmińsko-mazurskim. Wzrost produkcji ze źródeł odnawialnych nastąpił w niemal wszystkich województwach z wyjątkiem małopolskiego (spadek o 3\%). Największy wzrost produkcji energii ze źródeł odnawialnych dotyczy takich województw, jak: podlaskie, łódzkie, śląskie wielkopolskie. Wzrost produkcji energii elektrycznej z nieodnawialnych źródeł energii dotyczy tylko województw: łódzkiego, świętokrzyskiego, lubuskiego i zachodniopomorskiego. Największy wzrost produkcji energii elektrycznej zaobserwowany w warmińsko-mazurskim pochodzi głównie ze źródeł odnawialnych.

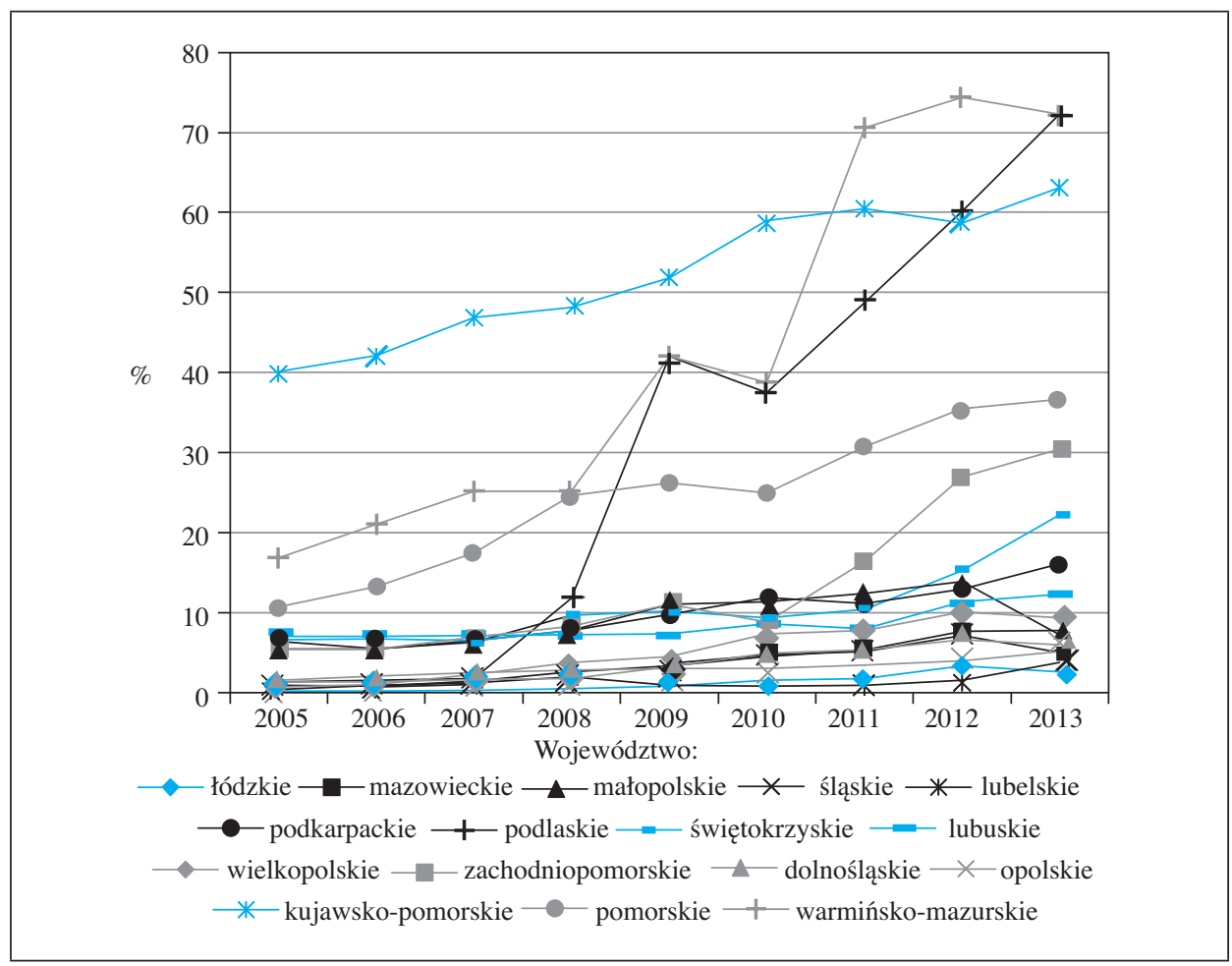

Rys. 2. Udział energii ze źródeł odnawialnych w produkcji energii elektrycznej w Polsce w latach 2005-2013 według województw

Źródło: opracowanie własne. 
We wszystkich województwach w latach 2005-2013 zaobserwowano wzrost udziału wykorzystania źródeł odnawialnych w produkcji energii elektrycznej (por. rys. 2). Najmniejszy wzrost nastąpił w województwie małopolskim (tylko o 33\%), kujawsko-pomorskim (o 57\%) i lubuskim (o 76\%). Największy, ponad 54-krotny, wzrost zaobserwowano w województwie podlaskim (z 1,3\% do 72,3\%), duży, bo aż 16-krotny, wzrost odnotowano w województwie w śląskim, zaś w województwach łódzkim i wielkopolskim nastąpił 13-krotny wzrost udziału energii ze źródeł odnawialnych.

\section{Zanieczyszczenie powietrza i wody}

Zanieczyszczenie powietrza mierzone jest głównie wielkością emisji zanieczyszczeń gazowych i pyłowych z zakładów szczególnie uciążliwych. Największą emisję zanieczyszczeń gazowych z zakładów szczególnie uciążliwych w t/rok w przeliczeniu na $\mathrm{km}^{2}$ odnotowano w województwach: śląskim, łódzkim i opol-

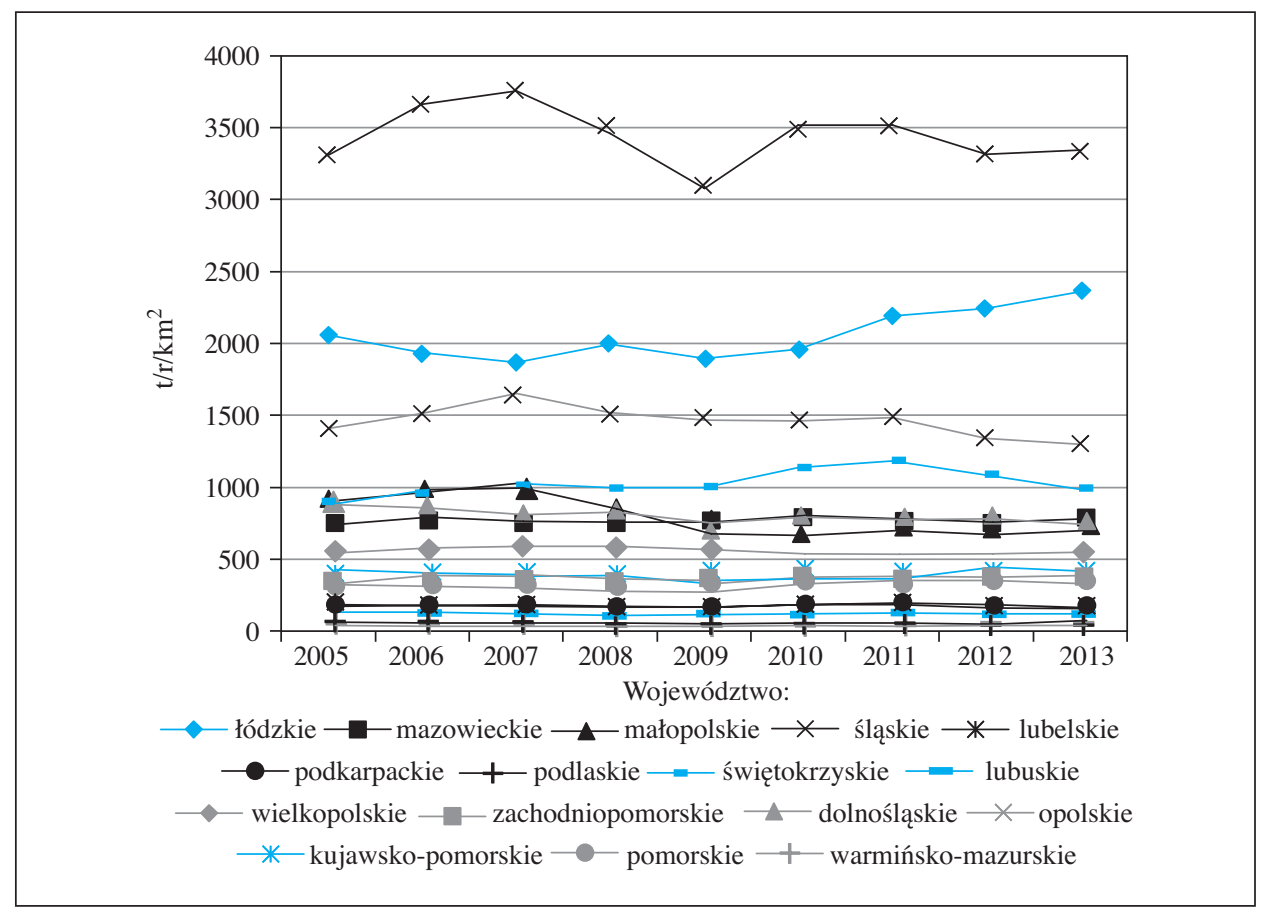

Rys. 3. Emisja zanieczyszczeń gazowych powietrza z zakładów szczególnie uciążliwych $\left(\mathrm{t} / \mathrm{r} / \mathrm{km}^{2}\right)$ w Polsce w latach 2005-2013 według województw

Źródło: opracowanie własne. 
skim. Najmniejsza emisja występuje w województwie warmińsko-mazurskim i podlaskim. Wzrost emisji w latach 2005-2013 nastąpił w województwie świętokrzyskim (o 26\%), zachodniopomorskim (o 17\%), łódzkim (o 14\%), spadek zaś w małopolskim (o 20\%), dolnośląskim (o 15\%) i lubelskim (o 10\%).

Największą emisją zanieczyszczeń pyłowych z zakładów szczególnie uciążliwych $\mathrm{w} \mathrm{t} / \mathrm{rok} \mathrm{w}$ przeliczeniu na $\mathrm{km}^{2}$ charakteryzuje się województwo śląskie (spadek z 1,82 w 2005 r. do 0,86 w 2013 r.). Duża emisja zanieczyszczeń pyłowych z zakładów szczególnie uciążliwych w t/rok w przeliczeniu na $\mathrm{km}^{2}$ występuje w województwach: małopolskim, świętokrzyskim i opolskim. Najmniejszą emisję zaobserwowano w warmińsko-mazurskim i podlaskim. We wszystkich województwach nastąpił spadek emisji zanieczyszczeń pyłowych w 2013 r. w stosunku do 2005 r. Największy spadek emisji dotyczy województwa lubelskiego (o 70\%), małopolskiego (o 61\%), łódzkiego, mazowieckiego i lubuskiego (o 60\%). Najmniejszy spadek zaobserwowano w województwie pomorskim (tylko о $33 \%)$.

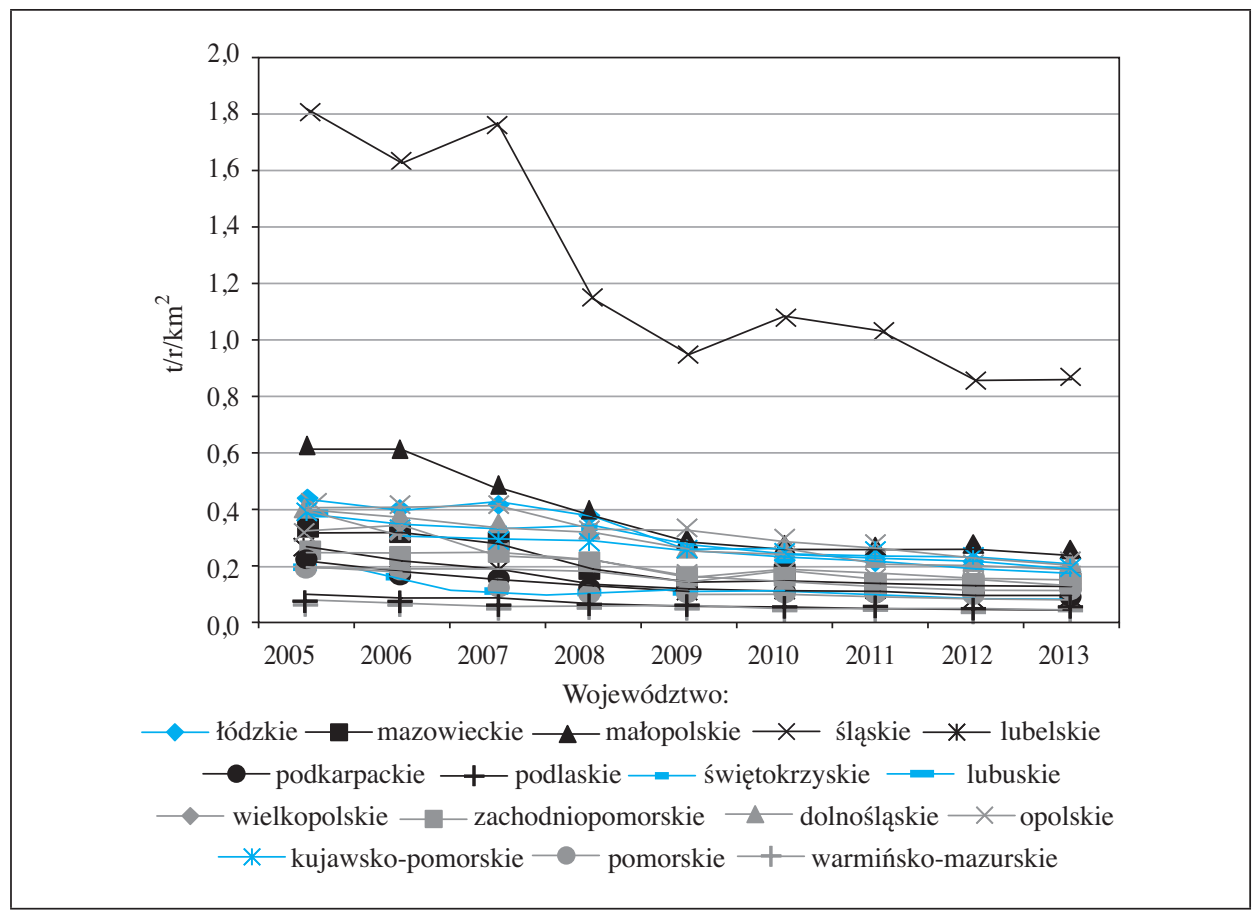

Rys. 4. Emisja zanieczyszczeń pyłowych powietrza z zakładów szczególnie uciążliwych $\left(\mathrm{t} / \mathrm{r} / \mathrm{km}^{2}\right)$ w Polsce w latach 2005-2013 według województw Źródło: opracowanie własne. 


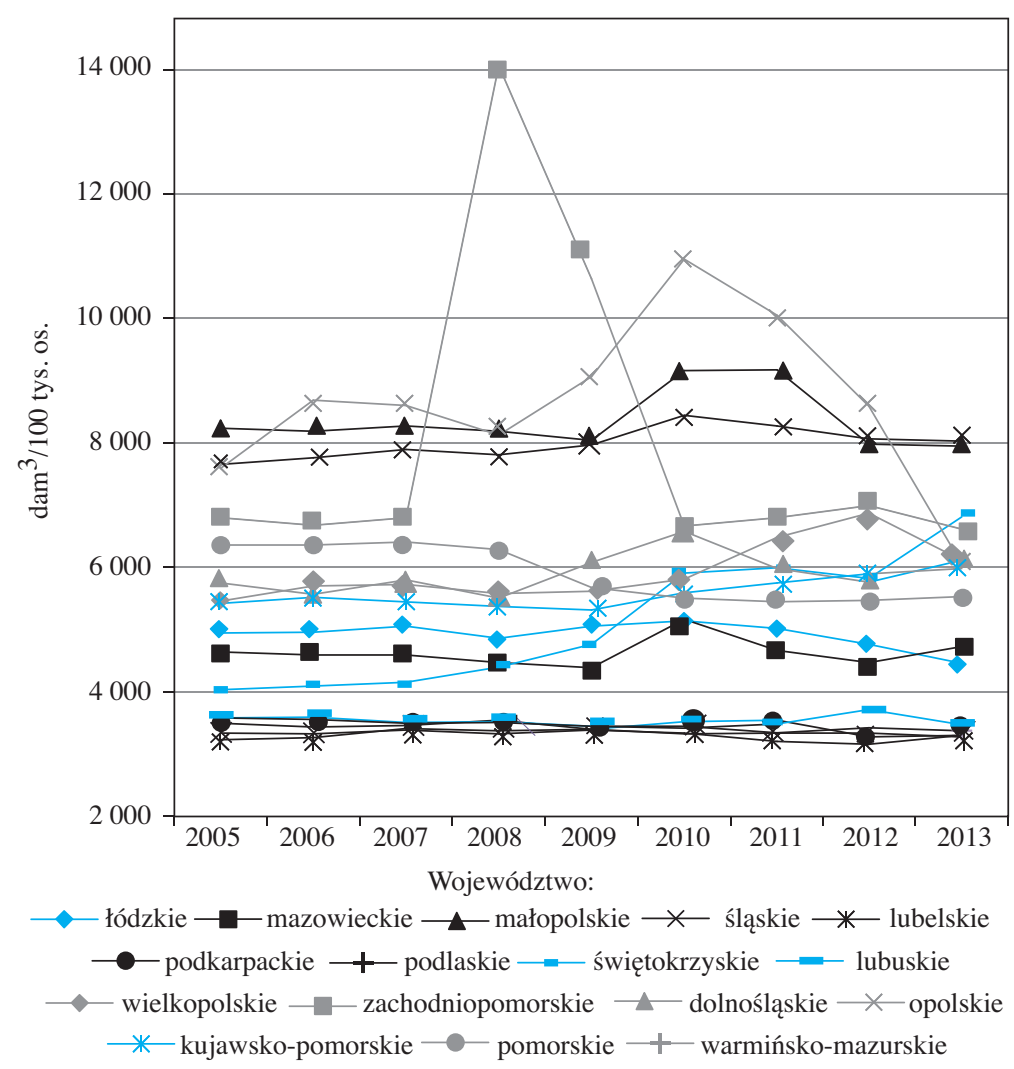

Rys. 5. Ścieki przemysłowe i komunalne wymagające oczyszczania odprowadzone do wód lub do ziemi w ciągu roku (dam³/100 tys. mieszkańców) w Polsce w latach 2005-2013 według województw

Źródło: opracowanie własne.

Ścieki przemysłowe i komunalne wymagające oczyszczania odprowadzone do wód lub do ziemi w ciągu roku w przeliczeniu na 100 tys. mieszkańców odzwierciedlają w badaniach zanieczyszczenie wód. Najwięcej ścieków w badanym okresie odprowadzały województwa: śląskie i małopolskie, a najmniej warmińsko-mazurskie, lubuskie, podlaskie, podkarpackie i lubelskie. Połowa województw zanotowała wzrost wielkości ścieków odprowadzanych do wód powierzchniowych i rzek, zaś druga połowa spadek. Największy wzrost zanotowano w świętokrzyskim (o 69\%), a największy spadek w opolskim (o 20\%). 


\section{Zależności pomiędzy produkcją energii elektrycznej a zanieczyszczeniem}

W celu zbadania czy występuje zależność pomiędzy wielkością produkcji elektrycznej a wielkością zanieczyszczenia powietrza i wody wykorzystano współczynnik korelacji liniowej.

Tabela 2. Współczynnik korelacji liniowej między produkcją energii elektrycznej a emisją zanieczyszczeń gazowych

\begin{tabular}{|l|c|c|c|c|c|c|c|c|c|}
\hline Rok & 2005 & 2006 & 2007 & 2008 & 2009 & 2010 & 2011 & 2012 & 2013 \\
\hline $\begin{array}{l}\text { Współczynnik } \\
\text { korelacji liniowej }\end{array}$ & 0,77 & 0,73 & 0,73 & 0,73 & 0,76 & 0,75 & 0,76 & 0,76 & 0,75 \\
\hline
\end{tabular}

Źródło: opracowanie własne.

Analiza tabeli 2 potwierdza, że występuje silna zależność liniowa pomiędzy wielkością produkcji energii elektrycznej ogółem a emisją zanieczyszczeń gazowych.

Przeprowadzono także analizę zależności emisji zanieczyszczeń gazowych i produkcji energii elektrycznej według źródeł (odnawialne i nieodnawialne) oraz udziału energii ze źródeł odnawialnych w produkcji energii elektrycznej. W przypadku zależności między produkcją z nieodnawialnych źródeł i emisji zanieczyszczeń gazowych rezultaty były analogiczne jak w tabeli 2 . W pozostałych przypadkach (odnawialne źródła energii oraz udział energii odnawialnej w ogólnej wielkości produkcji) nie występowały statystycznie istotne zależności.

Tabela 3. Współczynnik korelacji liniowej między produkcją energii elektrycznej a emisją zanieczyszczeń pyłowych

\begin{tabular}{|l|c|c|c|c|c|c|c|c|c|}
\hline Rok & 2005 & 2006 & 2007 & 2008 & 2009 & 2010 & 2011 & 2012 & 2013 \\
\hline $\begin{array}{l}\text { Współczynnik } \\
\text { korelacji liniowej }\end{array}$ & 0,41 & 0,44 & 0,47 & 0,48 & 0,46 & 0,43 & 0,40 & 0,36 & 0,33 \\
\hline
\end{tabular}

Źródło: opracowanie własne.

Niemal identyczne rezultaty odnotowano, analizując zależności pomiędzy emisją zanieczyszczeń pyłowych i produkcją energii elektrycznej według źródeł oraz udziału energii ze źródeł odnawialnych w produkcji energii elektrycznej. Analiza tabeli 3 potwierdza, że występuje istotna (choć już nie tak silna, jak w przypadku zanieczyszczeń gazowych) dodatnia zależność liniowa pomiędzy wielkością produkcji energii elektrycznej ogółem a emisją zanieczyszczeń pyło- 
wych. Pozostałe warianty analizy nie pozwoliły stwierdzić, że występuje zależność pomiędzy produkcją energii ze źródeł odnawialnych a wielkością emisji zanieczyszczeń pyłowych.

Także na podstawie analizy zależności pomiędzy wielkością ścieków wymagających oczyszczenia doprowadzanych do wód i rzek oraz produkcją energii elektrycznej ze źródeł odnawialnych nie można potwierdzić badanej hipotezy o występowaniu takich zależności. Analiza tabeli 4 potwierdza, że występuje znacząca dodatnia zależność liniowa jedynie pomiędzy wielkością produkcji ogółem a wielkością ścieków.

Tabela 4. Współczynnik korelacji liniowej między produkcją energii elektrycznej a wielkością ścieków

\begin{tabular}{|l|c|c|c|c|c|c|c|c|c|}
\hline Rok & 2005 & 2006 & 2007 & 2008 & 2009 & 2010 & 2011 & 2012 & 2013 \\
\hline $\begin{array}{l}\text { Współczynnik } \\
\text { korelacji liniowej }\end{array}$ & 0,43 & 0,49 & 0,53 & 0,33 & 0,44 & 0,53 & 0,47 & 0,40 & 0,30 \\
\hline
\end{tabular}

Źródło: opracowanie własne.

Wykorzystując współczynnik korelacji liniowej, nie udało się potwierdzić hipotezy, że zwiększający się udział wykorzystania odnawialnych źródeł energii powoduje mniejsze zanieczyszczenie powietrza i wody. W kolejnym etapie zbudowano miernik syntetyczny opisujący stan zanieczyszczeń powietrza i wody. Miernik ten obliczono jako bezwzorcową miarą syntetyczną, która stanowi średnią arytmetyczną ze znormalizowanych wartości cech ${ }^{1}$. Miara ta ma postać:

gdzie:

$$
s_{i}=\frac{1}{m} \sum_{j=1}^{m} x_{i j}^{\prime}, \quad i=1, \ldots n, j=1, \ldots, m,
$$

$x_{i j}^{\prime}$ - znormalizowana wartość $j$-tej cechy dla $i$-tego obiektu,

$\mathrm{n}$ - liczba analizowanych obiektów (16 województw),

$m$ - liczba przyjętych cech: $x_{1}$ - emisja zanieczyszczeń gazowych, $x_{2}-$ emisja zanieczyszczeń pyłowych, $x_{3}$ - ścieki przemysłowe i komunalne wymagające oczyszczenia.

Ponieważ wykorzystane zmienne miały charakter destymulant, stąd im większa jest wartość miernika tym gorzej świadczy to o stanie środowiska naturalnego. Uporządkowanie województw ze względu na wartość zbudowanego miernika zaprezentowano na rys. 6. Najgorsza sytuacja w badanym okresie była

${ }^{1}$ Do tak skonstruowanej miary syntetycznej A. Malina i A. Zeliaś [1998] proponują zastosowanie standaryzacji. W prowadzonej analizie zastosowano standaryzację ze stałymi parametrami w czasie. 
w województwie śląskim, a najlepsza w województwach: podlaskim, warmińsko-mazurskim, lubelskim, podkarpackim i lubuskim.

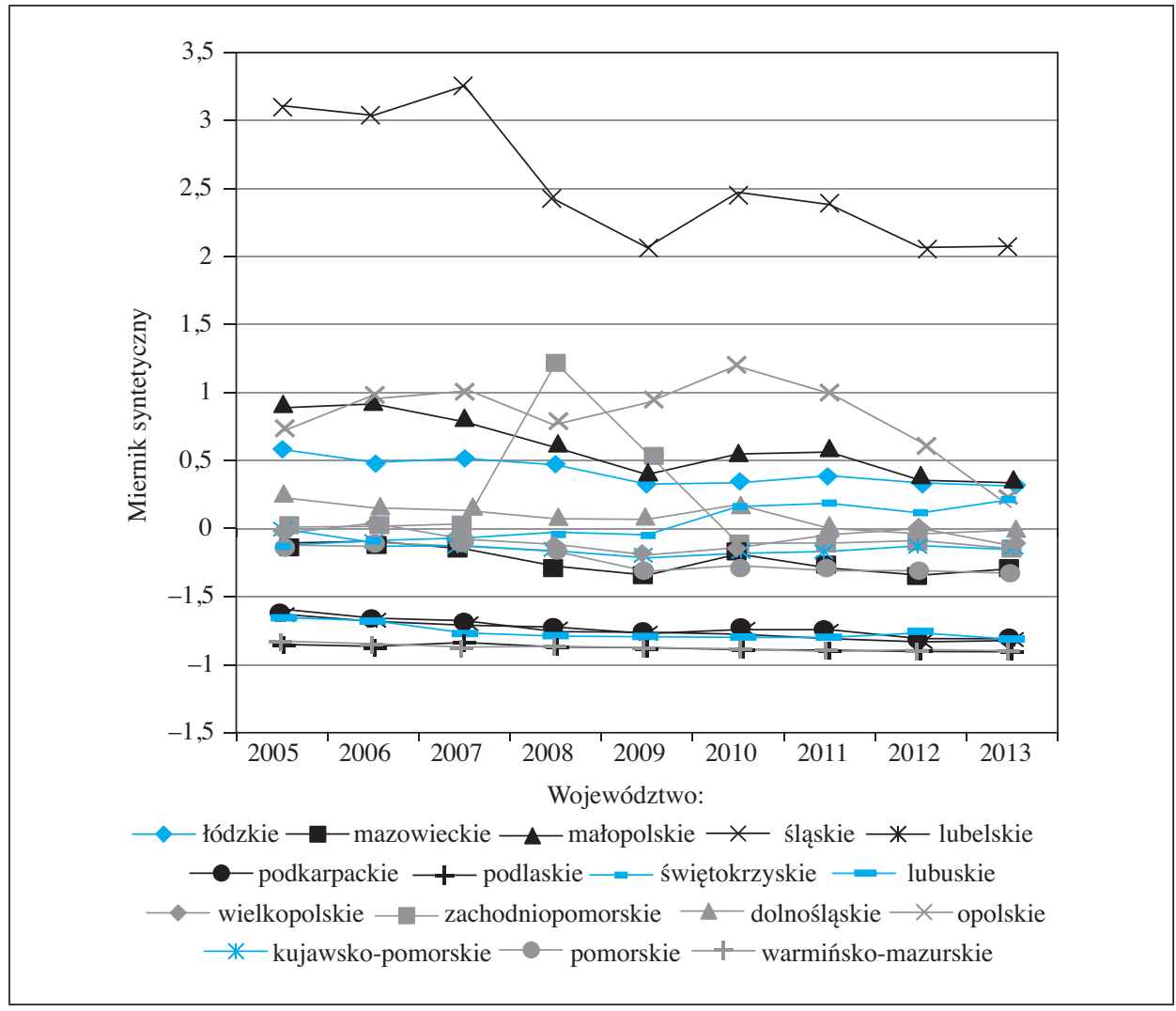

Rys. 6. Wartości miernika syntetycznego dla poszczególnych województw w latach 2005-2013

Źródło: opracowanie własne.

Wykorzystując współczynnik tau-Kendalla obliczony zgodnie z formułą zaprezentowaną w pracy [Walesiak 2006], sprawdzono zgodność uporządkowań województw w kolejnych latach. Analiza tabeli 5 potwierdza zgodność uporządkowań pomiędzy wielkością produkcji ogółem a miernikiem opisującym stan im większa produkcja tym gorszy stan środowiska. Podobne wyniki dała analiza zgodności uporządkowań ze względu na produkcję energii ze źródeł nieodnawialnych a stanem zanieczyszczeń. Również tu analiza zgodności uporządkowań ze względu na produkcję energii ze źródeł odnawialnych (oraz udział 
tej energii w ogólnej wielkości produkcji) nie dała podstaw do potwierdzenia badanej hipotezy.

Tabela 5. Współczynnik tau Kendalla pomiędzy uporządkowaniem ze względu na miernik i produkcję energii elektrycznej

\begin{tabular}{|l|c|c|c|c|c|c|c|c|c|}
\hline Rok & 2005 & 2006 & 2007 & 2008 & 2009 & 2010 & 2011 & 2012 & 2013 \\
\hline $\begin{array}{l}\text { Współczynnik } \\
\text { tau Kendalla }\end{array}$ & 0,58 & 0,70 & 0,68 & 0,63 & 0,62 & 0,68 & 0,72 & 0,68 & 0,67 \\
\hline
\end{tabular}

Źródło: opracowanie własne.

Na koniec postanowiono pogrupować województwa ze względu na zmienne opisujące stan zanieczyszczeń w 2013 r. i przyjrzeć się strukturze produkcji energii w poszczególnych grupach. Województwa grupowano na podstawie wykorzystywanych wcześniej zmiennych: $x_{1}-$ emisja zanieczyszczeń gazowych, $x_{2}-$ emisja zanieczyszczeń pyłowych, $x_{3}$ - ścieki przemysłowe i komunalne wymagające oczyszczenia.

Dane poddane zostały normalizacji (zastosowana została standaryzacja). Jako metodę klasyfikacji przyjęto ostatecznie metodę Warda z odległością Euklidesa (zob. [Grabiński, Wydymus i Zeliaś 1989, Malina, Pawełek, Wanat i Zeliaś 1998]). Na podstawie analizy wartości indeksu Silhouette (zob. [Kaufman i Rousseeuw 1990) podzielono województwa na 4 grupy. Przeprowadzono ocenę wyników klasyfikacji ${ }^{2}$ z wykorzystaniem skorygowanego indeksu Randa, wartość miernika potwierdziła poważną strukturę klas. Wyniki grupowania prezentuje rys. 7.

W tabeli 6 dla każdej z czterech wyróżnionych klas podano podstawowe statystyki (średnią, medianę, wartość minimalna oraz maksymalną, a także odchylenie standardowe) dotyczące badanych zmiennych dotyczących zanieczyszczenia powietrza i wody.

Jednoelementowa grupa I, czyli województwo łódzkie, charakteryzuje się dużym zanieczyszczeniem, szczególnie jeśli chodzi o powietrze. Jednocześnie jest to województwo, w którym udział energii ze źródeł odnawialnych w ogólnej produkcji energii elektrycznej jest najmniejszy w Polsce (w 2013 r. tylko 2,6\%). Grupa II, czyli województwo śląskie, to grupa w której zanieczyszczenie powietrza i wody jest największe w Polsce, zaś udział energii ze źródeł odnawialnych w ogólnej produkcji energii elektrycznej jest bardzo mały (w 2013 r. wynosił tylko $5,0 \%$ ). Grupa III, tj. województwa: mazowieckie, małopolskie, świętkorzystkie, wielkopolskie, zachodniopomorskie, dolnośląskie, opolskie, kujawsko-pomorskie

\footnotetext{
${ }^{2}$ Obliczenia przeprowadzono z wykorzystaniem funkcji replication.Mod pakietu ClusterSim w programie R. Wartość indeksu znajdowała się przedziale $(0,5-0,7]$ co wskazuje na ważną strukturę klas.
} 


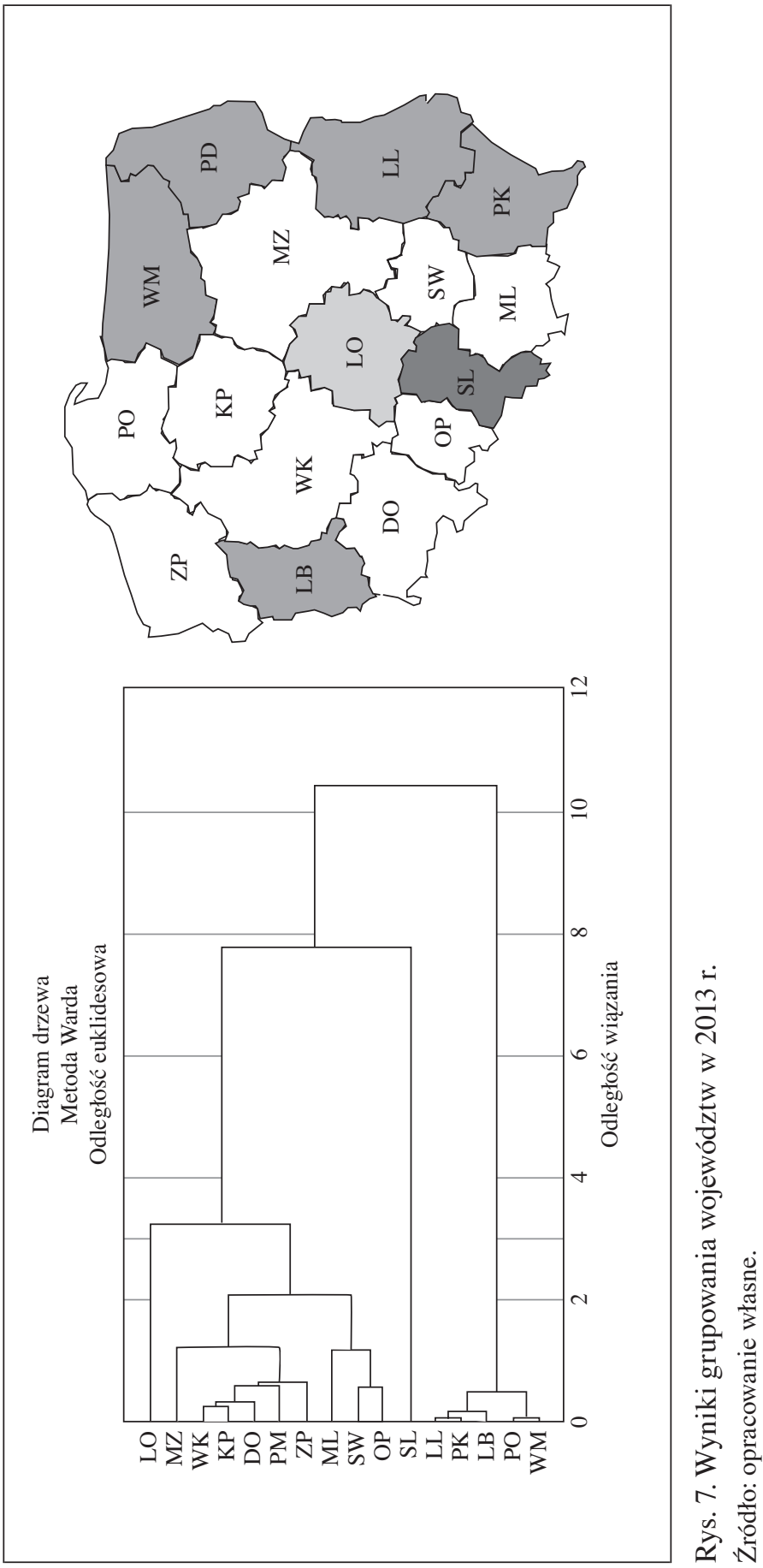


i pomorskie, to grupa w której obserwuje się znaczne zanieczyszczenie, szczególnie jeśli chodzi o wodę. Średni udział energii ze źródeł odnawialnych w ogólnej produkcji energii elektrycznej w tych województwach wynosił w 2013 r.: 20,9\%. Zdecydowanie najmniejsze zanieczyszczenie powietrza i wody dotyczy województw stanowiących grupę IV: lubelskiego, podkarpackiego, podlaskiego, lubuskiego i warmińsko-mazurskiego. Są to równocześnie województwa, w których średni udział energii ze źródeł odnawialnych w ogólnej produkcji energii elektrycznej wynosił w 2013 r. aż 35,4\%.

Tabela 6. Wartości statystyk wybranych zmiennych dla poszczególnych grup

\begin{tabular}{|l|c|c|c|c|c|c|}
\hline \multicolumn{1}{|c|}{ Grupa } & Zmienna & Średnia & Mediana & Minimum & Maksimum & $\begin{array}{c}\text { Odchylenie } \\
\text { standardowe }\end{array}$ \\
\hline \multirow{2}{*}{ I: LO } & gazowe & 2358,02 & 2358,02 & 2358,02 & 2358,02 & - \\
\cline { 2 - 7 } & pyłowe & 0,17 & 0,17 & 0,17 & 0,17 & - \\
\cline { 2 - 7 } & ścieki & 4454,18 & 4454,18 & 4454,18 & 4454,18 & - \\
\hline \multirow{2}{*}{ II: SL } & gazowe & 3342,45 & 3342,45 & 3342,45 & 3342,45 & - \\
\cline { 2 - 7 } & pyłowe & 0,86 & 0,86 & 0,86 & 0,86 & - \\
\cline { 2 - 7 } & ścieki & 8030,48 & 8030,48 & 8030,48 & 8030,48 & - \\
\hline \multirow{2}{*}{$\begin{array}{l}\text { III: MZ, ML, SW, } \\
\text { KP, PM }\end{array}$} & gazowe & 707,15 & 724,58 & 355,63 & 1297,06 & 303,26 \\
\cline { 2 - 7 } & pyłowe & 0,17 & 0,19 & 0,11 & 0,24 & 0,04 \\
\cline { 2 - 7 } $\begin{array}{l}\text { IV: LL, PK, PD, } \\
\text { LB, WM }\end{array}$ & ścieki & 6209,97 & 6112,44 & 4722,52 & 7947,10 & 887,28 \\
\cline { 2 - 7 } & gazowe & 135,48 & 143,66 & 65,87 & 188,25 & 53,057 \\
\cline { 2 - 7 } & ścieki & 3346,02 & 3306,03 & 3275,49 & 3473,59 & 80,643 \\
\hline
\end{tabular}

Źródło: opracowanie własne.

Analiza udziału energii ze źródeł odnawialnych w ogólnej produkcji energii elektrycznej w poszczególnych grupach pozwala częściowo potwierdzić zależności pomiędzy wykorzystaniem energii ze źródeł odnawialnych i stanem zanieczyszczeń, zwłaszcza że otrzymane grupy województw były bardzo jednorodne ze względu na wartości zmiennych opisujących stan zanieczyszczeń.

\section{Wnioski}

$\mathrm{Z}$ analizy danych wynika, że wzrost produkcji energii elektrycznej w wielu województwach jest związany ze wzrostem wykorzystania energii odnawialnej. Zaobserwowana tendencja jest zjawiskiem korzystnym. Zanieczyszczenia gazowe w Polsce pozostają na niezmienionym poziomie, natomiast maleje we wszystkich 
województwach emisja zanieczyszczeń pyłowych. Również wielkość ścieków przemysłowych i komunalnych wymagających oczyszczenia odprowadzanych do wód i rzek wykazuje tendencję malejącą.

Analiza współczynnika korelacji liniowej pozwoliła potwierdzić jedynie dodatnią zależność pomiędzy produkcją energii ogółem a zanieczyszczeniami. Szczególnie w przypadku emisji zanieczyszczeń gazowych wartości współczynnika wskazują, że wzrost produkcji energii elektrycznej wpływa na wzrost emisji zanieczyszczeń. Także analiza współczynnika tau-Kendalla potwierdza zgodność uporządkowań ze względu na miernik opisujący stan zanieczyszczeń z uporządkowaniem ze względu na wielkość produkcji energii elektrycznej ogółem.

W przypadku grupowania województw ze względu na zmienne opisujące stan zanieczyszczeń powietrza i wody widoczne są różnice w udziale energii ze źródeł odnawialnych w produkcji energii elektrycznej w poszczególnych grupach. Przeprowadzona analiza pozwoliła tylko częściowo potwierdzić badaną hipotezę. Wynika z niej, że ogólnie wzrost produkcji energii elektrycznej jest związany ze wzrostem zanieczyszczenia. Nie udało się jednak zdecydowanie potwierdzić, że w województwach, gdzie energia elektryczna produkowana jest głównie ze źródeł odnawialnych, wielkość zanieczyszczeń powietrza i wody spada w sposób widoczny, czy też wzrost zanieczyszczeń jest mniejszy niż rejonach, gdzie udział energii ze źródeł odnawialnych jest zdecydowanie mniejszy.

\section{Literatura}

Dyrektywa 2009/28/WE z dnia 23 kwietnia 2009 r. w sprawie promowania stosowania energii ze źródeł odnawialnych zmieniająca i w następstwie uchylająca dyrektywy 2001/77/WE oraz 2003/30/WE. Dziennik Urzędowy Unii Europejskiej L 140/16, 5.6.2009.

Grabiński T., Wydymus S., Zeliaś A. [1989], Metody taksonomii numerycznej w modelowaniu zjawisk społeczno-gospodarczych, PWN, Warszawa.

Kaufmann L., Rousseeuw P.J. [1990], Finding Groups in Data: An Introduction to Cluster Analysis, Wiley, New York.

Malina A., Pawełek B., Wanat S., Zeliaś A. [1998], Statystyczne metody oceny ryzyka w przedsiębiorstwie, Wydawnictwo Akademii Ekonomicznej w Krakowie, Kraków.

Malina A., Zeliaś A. [1998], Taksonomiczna analiza przestrzennego zróżnicowania warunków życia ludności w Polsce w latach 1994 i 1995, Prace Naukowe WSPiM w Chrzanowie, nr 2.

Walesiak M. [2006], Uogólniona miara odległości w statystycznej analizie wielowymiarowej, wyd. 2 rozszerzone, Wydawnictwo Akademii Ekonomicznej im. Oskara Langego we Wrocławiu, Wrocław. 


\section{How the Use of Renewable Energy Influences the Quality of the Natural Environment: The Case of Poland}

(Abstract)

The use of different energy sources is an increasingly serious challenge for the countries for which sustainable development also means better use of energy resources and environmental improvement. The production and use of energy influences our living standards, but at the same time degrades and destroys the environment. The main aim of the study is to assess the impactthe energy sources used have on the natural environment in Poland. The paper discusses changes in how energy is acquired from traditional and renewable sources in individual provinces in Poland.It also analyses the state of the natural environment, with particular reference to air and water pollution. An attempt is made to assess whether increasing the use of renewable energy sources has a positive impact on reducing environmental degradation.

Keywords: renewable energy, air and water pollution, linear ordering, classification. 